\title{
The Role of I Region Gene Products in Macrophage - T Lymphocyte Interaction
}

\author{
JOHN E. NIEDERHUBER
}

\section{INTRODUCTION}

The macrophage first gained recognition in the early 1920's and 1930's as the cell responsible for clearing antigen and synthesizing antibody (Sabin 1923). Its importance to the immune response faded with the realization that lymphocytes and not macrophages were the origin of antibody molecules and it was not until the early 1960's that experiments suggested that antigen processing by the macrophage was required for stimulation of immunocompetent lymphocytes (Fishman \& Adler 1963). This renewed interest, however, was short lived when it was demonstrated that antigens could be recognized by lymphocytes. Furthermore, although lymphocytes could interact with macrophage bound antigen it did not appear critical that this antigen be processed, or structurally altered, by the macrophage.

Recently, the macrophage has again become the center of immunologic attention, with the recognition that the immune response to T-cell dependent antigens requires the participation of at least three distinct classes of immunocompetent cells: macrophages, thymus-derived cells $(T)$, and thymus independent antibody forming cell precursors (B cells) (Claman \& Mosier 1972, Katz \& Benacerraf 1972, Unanue 1972, Pierce \& Kapp 1976). It is clear that the macrophage is intimately involved in antigen presentation to $\mathrm{T}$ and $\mathrm{B}$ lymphocytes and that in the initiation of the response it acts as a focal point for cell interaction. It is also responsible for the production of a number of mediators which intimately effect the response to antigen.

We have demonstrated that a subpopulation of macrophages expresses

Departments of Microbiology and Surgery, The University of Michigan Medical Center, Ann Arbor, Michigan 48109, U.S.A. 
TABLE I

Distribution of $\mathrm{H}-2$ regions and Ia specificities

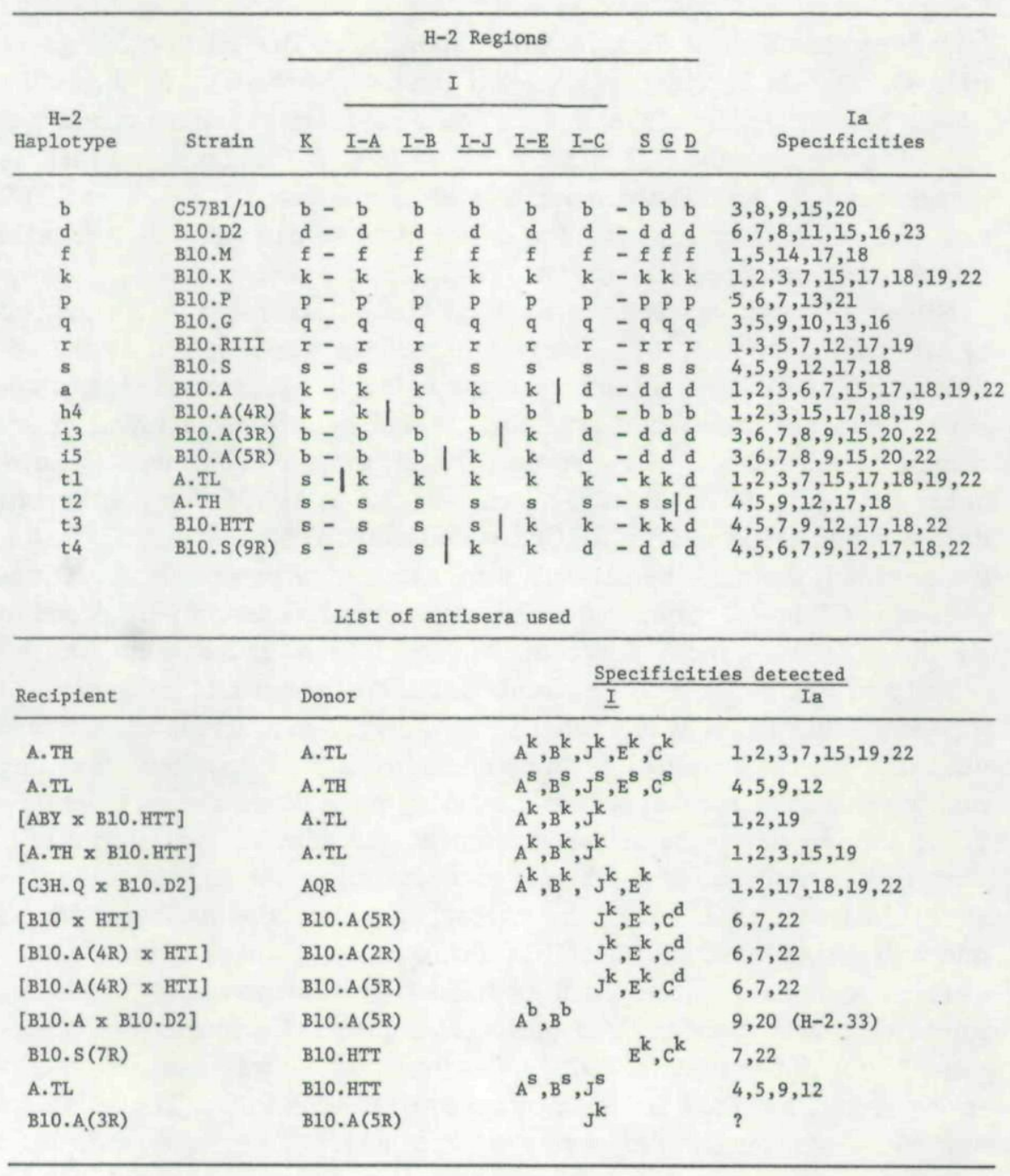

the Ia membrane antigen(s) and that it is this subset of macrophages that is required for an in vitro antibody response. The $I$ region determinant(s) required for this primary response and for efficient macrophage-T lymphocyte interaction appear restricted to the $I-J$ subregion. The experiments leading to these conclusions are presented in this review. 


\section{METHODOLOGY}

Congenic mice were produced in our colony at the University of Michigan from breeders obtained from Jackson Laboratories, Bar Harbor, Maine, or from Dr. Donald Shreffler, Washington University School of Medicine, St. Louis, Missouri. The congenic mice used in these experiments are described in terms of the $\mathrm{H}$-2-allelic origin of their $\mathrm{H}-2$ regions and their Ia specificities (Table I). Restricted anti-Ia sera, as listed in Table I, anti-H-2 sera and allo-antisera specific for differentiation markers were prepared as previously described (David et al. 1973, David 1976).

Dispersed spleen cell cultures were established according to the method of Mishell \& Dutton (1967). The culture medium was modified by the addition of 0.01-M HEPES buffer and the antibiotic gentamycin. Mercaptoethanol was not added to the cultures. Adherent cells were prepared according to the method of Pierce (1974) with some modifications (Niederhuber \& Shreffler 1977). Briefly, spleen cells $\left(1.5 \times 10^{7} / 35 \mathrm{~mm}\right.$ plastic petri dish, No. 3001 Falcon, Oxnard, Ca.) were incubated for $2.5 \mathrm{~h}$ at $37^{\circ} \mathrm{C}$, following which the nonadherent cells were decanted. Appropriate concentrations of anti-Thy-1.2 serum and rabbit anti-mouse-IgG serum were added to the dishes, and the incubation continued for $30 \mathrm{~min}$. The antisera was decanted and spleen-cell, agarose-adsorbed, EDTA-treated rabbit complement was added and the cells incubated for another $30 \mathrm{~min}$. The adherent cells were then carefully washed by three additions of fresh medium, decanting each addition. The number of cells remaining in the dishes ranged from 0.5$1.5 \times 10^{6}$. At this point in the experiment, the adherent phagocytic cells were treated with anti-Ia antibodies as described in the individual experiments. In recent experiments, the macrophages were also incubated for 30 min with mitomycin-C ( $40 \mu \mathrm{gm} / 10^{7}$ cells $\left./ \mathrm{ml}\right)$ prior to use in culture.

The macrophage-depleted cell population was prepared by incubating spleen cells with carbonyl iron powder (Atomergic Chemicals Co., Plainview, N.Y.) (Sjöberg et al. 1972). The iron powder was removed with a strong magnet and the iron treatment repeated a second time. The cells were washed by centrifugation in culture medium and $10^{7}$ macrophage depleted cells were added to anti-Ia antibody treated adherent phagocytic cells to reconstitute the cultures. Cultures were stimulated with $10^{7}$ Burro erythrocytes (BRBC) and assayed for class specific PFC on Day 5 of the in vitro culture (Jerne \& Nordin 1963, Dresser \& Wortis 1965, Bullock \& Möller 1972). The dishes were individually assayed by sampling twice and the mean and standard deviation of quadruplicate cultures were determined. Groups within an experiment were compared using Student's t distribution for paired observations. The experimental model is depicted in Figure 1. 


\section{EXPERIMENTAL RESULTS}

\section{Preparation and characterization of cell fractions}

It is obvious that the interpretation of experiments involving manipulation of lymphocyte subpopulations depends heavily on the relative purity of the isolated fractions. Therefore, a great deal of effort has been directed at characterizing the subpopulation of adherent splenic cells termed macrophages. If spleen cells were incubated in plastic dishes for $2.5 \mathrm{~h}$ and the non-adherent cells removed by decanting and gently washing the adherent cells with fresh media, the adherent macrophage population was contaminated by adherent $\mathrm{T}$ and B cells. Scanning electron microscopy showed that $40 \%$ of the adherent cells were lymphoid in character. This population of adherent cells had a normal proliferative response to Con-A or LPS. The response of the adherent cells to these mitogens was further evidence of considerable contamination with lymphoid cells. The stimulation of the adherent macrophages with BRBC in Mishell-Dutton culture resulted in a markedly reduced PFC response. The addition of small numbers of nylon wool purified $\mathrm{T}$ lymphoid cells however, completely restored the PFC response and confirmed the presence of significant numbers of antibodyforming cell precursors (B cells). By treating the adherent cell fraction with anti-Thy 1.2 sera, rabbit anti-mouse IgG sera and complement, the resistant adherent cells were no longer responsive to T-cell mitogens or to LPS. When nylon wool $\mathrm{T}$ cells were added to these antisera purified macrophages, they could not restore the PFC response to BRBC in the Mishell-Dutton assay. The antiserum purified splenic macrophages were incubated with latex

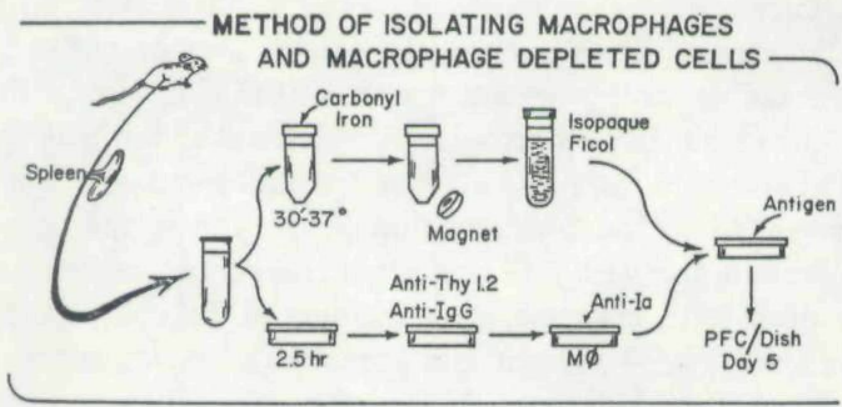

Figure 1. Preparation of highly purified adherent macrophage populations and macrophage depleted T-B cell fractions. We have found the additional step of centrifugation of the macrophage-depleted lymphocytes on a sodium metrizoate Ficoll gradient to be unnecessary. Macrophages are now blocked with mitomycin- $\mathrm{C}$ after they have been treated with anti-Ia sera. 
beads and $>95 \%$ of the cells were phagocytic. A similar conformation of macrophage purity was observed with special esterase stains of the macrophage preparation.

Several methods of depleting the $\mathrm{T}$ cell-B cell fraction of macrophages were compared to the population of nonadherent cells decanted from the petri dishes after $2.5 \mathrm{~h}$ of incubation. These methods included double incubation of spleen cells with carbonyl iron powder (Sjöberg et al. 1972) or filtration of the spleen cells through small columns of Sephadex G-10 (LY \& Mishell 1974) after which the cells were incubated with carbonyl iron. These two methods resulted in a T cell-B cell fraction which consistently contained less than $5 \%$ cells capable of phagocytosis. It should be noted that the yield of cells obtained by decanting non-adherent cells per number of mice used was much lower than could be obtained with either the carbonyl iron or the Sephadex G-10 techniques. As we could see no difference in functional assays, including the in vitro cultures for antibody response, the $\mathrm{T}$ cell-B cell fractions were prepared by incubation with carbonyl iron powder.

The macrophage depleted $\mathrm{T}$ cell-B cell fraction did not respond to antigen stimulation but responded normally in proliferative assays to Con A or LPS. Approximately $50 \%$ of this fraction was stained by fluorescein conjugated rabbit-anti-mouse kappa chain sera. Using this technique to quantitate the number of B cells, it could be estimated that $20-30 \%$ of the B cells were lost during preparation of this cell fraction.

\section{Characteristics of the in vitro antibody response using macrophages and macrophage depleted cell fractions}

Initial experiments testing the purity of the macrophage population adhering to the plastic petri dishes demonstrated a low level of antibody response when culture dishes were stimulated with BRBC. This low PFC response disappeared when adherent macrophages were further purified by treatment with anti-Thy 1.2 sera, anti-IgG sera and complement. To test the purity of the macrophage preparation, adherent phagocytic spleen cells were prepared as described, but with different initial cell concentrations added to the dishes. The number of macrophages remaining in the dishes following antiThy 1.2 sera plus anti-IgG sera and complement treatment was approximately $10 \%$ of the initial cell concentration. No response to BRBC was obtained in dishes containing as many as $5 \times 10^{6}$ macrophages. This was further evidence for the purity of the macrophage fraction. For example, if $\mathrm{T}$ and $\mathrm{B}$ lymphoid cells, a subpopulation of which also adheres to the dishes, were not removed by antisera and complement a low PFC response 
was obtained which increased with increasing numbers of adherent cells.

The macrophage depleted population was examined in a similar manner. That is, increasing numbers of macrophage depleted cells were cultured alone with BRBC. No PFC response was obtained even when as many as $5 \times 10^{7} / \mathrm{ml}$ macrophage-depleted $\mathrm{T}$ and $\mathrm{B}$ cells were cultured (PFC/dish $<10$ ). When a dose curve of the T-B fraction was added to dishes containing $\sim 10^{6}$ macrophages, the maximum PFC response occurred with the addition of $10^{7}$ T-B fraction cells. The degree of 'reconstitution' of the response was always compared to an equal number of unfractionated spleen cells and this varied from $50-100 \%$.

The macrophages were harvested from the dishes with a sterile rubber policeman or by gentle lidocaine treatment (ASTRA, Worchester, Mass.) (Rabinovitch \& DeStefano 1975) washed by centrifugation in culture media and different numbers added to $10^{7} \mathrm{~T}-\mathrm{B}$ fraction cells. The peak response was always found with the addition of $10^{5}-10^{6}$ macrophages. The addition of more macrophages promptly brought the PFC response to background levels. Treatment of the macrophages with mitomycin-C did not alter the observed dose curve except that in some experiments less suppression of the PFC response with increasing numbers of macrophages $\left(>10^{6}\right)$ was observed.

The observation of a rather narrow ratio for effective reconstitution of the response is important and as yet not fully understood. It is hard to explain the marked decrease in the PFC response to background levels without implicating and active suppressor role for the macrophage population.

The requirement for an Ia-bearing macrophage in the in vitro antibody response

The adherent phagocytic cells of the spleen (macrophages) and the macrophage population obtained from the mouse peritoneal cavity can be divided into Ia-positive and Ia-negative subpopulations (Hämmerling 1976, Niederhuber \& Shreffler 1977, Schwartz et al. 1977). The percentage of splenic macrophages which have detectable Ia determinants varies from preparation to preparation but is most often $1 / 3$ of the isolated macrophages (range 23$50 \%)$. A smaller number $(\sim 15 \%)$ of the isolated and purified peritoneal macrophages bear the Ia molecule(s).

To test the requirement for Ia bearing macrophages in the primary in vitro antibody response, macrophages were treated with broadly specific anti-Ia sera and rabbit complement. Control sera inappropriate for the target macrophages and complement was also used. Following the antisera and complement treatment, the adherent macrophages were washed by gently adding 
fresh media to the dish and decanting. This washing of the resistant cells was repeated three times. A macrophage depleted T-B cell fraction was added to the dishes and the culture stimulated with BRBC. By counting the macrophages remaining in parallel dishes not used in the culture, it was determined that $23-30 \%$ of the cells were lost due to anti-Ia sera plus complement treatment. The macrophages resistant to anti-Ia serum and complement were not capable of reconstituting the antibody response (Niederhuber et al. 1977, 1978).

Deletion experiments must be carefully controlled and are often difficult to interpret. If the Ia bearing macrophage was the only cell deleted by anti-Ia antibody and complement treatment and was the cell population essential to the initiation and maintenance of the in vitro antibody response, the addition of normal untreated macrophages should reconstitute the response when added to a culture containing anti-Ia sera plus complement treated macrophages and the T-B cell fraction. Such an experiment is shown in Figure 2. Obviously the credibility of such experiments to answer these questions depends wholely on the purity of the populations of cells manipulated in a given experiment, an aspect of these experiments which has been of great concern.

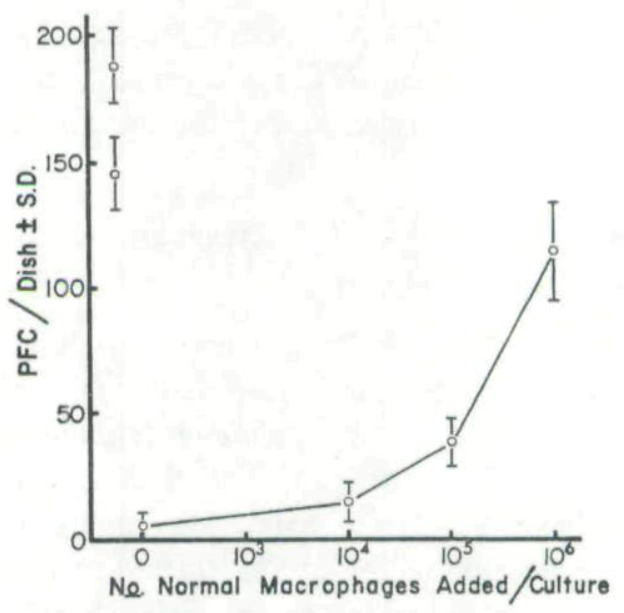

Figure 2. Primary IgM-PFC response measured on Day 5 of the culture period. The target cells were B10.BR $\left(H-2^{k}\right)$ and cultures were stimulated with BRBC. The controls for the experiment consisted of untreated macrophages (highest circle) and macrophages treated with A.TL anti-A.TH serum and complement. The appropriate anti-Ia sera used was (A.TH $\times$ B10.HTT) anti-A.TL which reduced the response to $<10 \mathrm{PFC}$ dish. Normal macrophages harvested from dishes not treated with anti-Ia sera were added to the anti-Ia sera and complement treated macrophages. 
Initial experiments, therefore, demonstrated that there was a sub-population of splenic macrophages that had detectable membrane Ia determinants and that the deletion of this subpopulation by anti-Ia antibody and complement resulted in a loss of the ability to support primary in vitro antibody response. The critical macrophage could be replaced and the in vitro response restored by the addition of normal macrophages to the cultures. It is also important to note that the viability of lymphoid cells in culture for 5 days was not lower in cultures depleted of Ia positive macrophages. These observations posed two questions: (1) Are the genetic markers of all $I$ subregions expressed on the macrophage membrane and therefore critical to the in vitro response or is this phenomenon genetically restricted? (2) Is the Ia molecule directly involved in antigen presentation and/or macrophage-T lymphocyte interaction?

\section{Mapping of I-region genes controlling Ia expression on splenic macrophages}

Two approaches were used to determine which $I$-region genes control the expression of the Ia determinants on the subpopulation of macrophages required for an in vitro antibody response. First, restricted anti-Ia sera were tested on different $I$-region recombinant strains. Second, a series of experiments was performed using restricted anti-Ia serum which was first adsorbed with selected recombinant strains before using with complement to delete target macrophages of a different strain. The use of a number of different anti-Ia sera and complement to treat the macrophage population of selected strains indicated that, although macrophages expressed a repertoire of Ia specificities similar to the lymphoid cells of that strain, antibodies directed at specificities of certain subregions were not effective in removing the macrophage function in a primary antibody response.

In these experiments additional dishes were processed for each experimental condition solely for the purpose of determining actual macrophage numbers remaining after anti-Ia sera and complement treatment. These results indicated that the same percentage of macrophages were lost with different appropriate anti-Ia sera and complement treatment regardless of the effect on the ability of the remaining macrophages to function in the antibody response. This observation indicates that the various sub-populations of macrophages, perhaps with different functions, express different Ia determinants.

The most critical experiments to the mapping of Ia determinants specific for the relevant macrophages were those using restricted anti-Ia sera which were then selectively adsorbed. These experiments are presented in Tables II and III. In Table II the adsorption of A.TH anti-A.TL serum with 
TABLE II

Effect on macrophage function in the in vitro antibody response by treatment with selectively adsorbed anti-Ia serum and complement

B10.BR k-kkkkk-kkk $[1,2,3,7,15,17,18,19,22]^{1}$

\begin{tabular}{|c|c|c|c|c|c|c|}
\hline \multirow{2}{*}{$\begin{array}{l}\text { Antiseirum Treatment } \\
\text { of Macrophages }\end{array}$} & \multirow{2}{*}{$\begin{array}{l}\text { Antiserum } \\
\text { Adsorbed with }\end{array}$} & \multirow{2}{*}{$\begin{array}{l}\text { Relevant } \frac{I}{2} \\
\text { Subregion }\end{array}$} & \multicolumn{4}{|c|}{$\begin{array}{c}\text { IgM } \\
\text { PFC/Dish } \pm \mathrm{SD}^{3}\end{array}$} \\
\hline & & & Exp. 1 & Exp. & 2 & \\
\hline - & - & - & $349 \pm 29$ & 244 & \pm & 9 \\
\hline A.TH anti-A.TL & - & $A_{B}^{k} k_{J} k_{E} k_{C} k$ & $48 \pm 9$ & & - & \\
\hline A.TH anti-A.TL & B10.S $(9 \mathrm{R})$ & $A^{k} B^{k}$ & $344 \pm 27$ & & - & \\
\hline A.TH ant1-A.TL & B10. HTT & $A^{k} B^{k} J^{k}$ & $123 \pm 24$ & & - & \\
\hline A.TH anti-A.TL & $\mathrm{B} 10 . \mathrm{A}(4 \mathrm{R})$ & $B^{k} J^{k} E^{k} C^{k}$ & $88 \pm 34$ & & - & \\
\hline A.TH anti-A.TL & B10.A & $c^{k}$ & $314 \pm 33$ & & - & \\
\hline (A.TH $\times$ B10.HTT) anti-A.TL & - & $A^{k} B^{k} J^{k}$ & $17 \pm 9$ & 1 & \pm & 2 \\
\hline (A.TH $\times$ B10.HTT) anti-A.TL & $B 10 . A(3 R)$ & $A^{k} B^{k} J^{k}$ & $43 \pm 15$ & 9 & \pm & 4 \\
\hline (A.TH $\times$ B10.HTT) ant1-A.TL & $\mathrm{B} 10 . \mathrm{A}(5 \mathrm{R})$ & $A^{k} B^{k}$ & $352 \pm 12$ & 158 & \pm & 5 \\
\hline (A.TH $\times$ B10.HTT) anti-A.TL & B10 & $A^{k} B^{k} J^{k}$ & $30 \pm 6$ & 10 & \pm 1 & 10 \\
\hline (A.TH $\times$ B10.HTT) anti-A.TL & $\mathrm{B} 10 . \mathrm{A}(4 \mathrm{R})$ & $B^{k} J^{k}$ & $62 \pm 5$ & 18 & \pm & 7 \\
\hline (A.TH $\times$ B10.HTT) ant1-A.TL & B10. A & none & - & 169 & \pm 2 & \\
\hline$(B 10 \times$ HTI) anti-B10.A(5R) & - & $J^{k} E^{k} C^{d}$ & - & 8 & \pm & 7 \\
\hline$(\mathrm{B} 10 \times \mathrm{HTI})$ ant1-B10.A(5R) & B10.D2 & $\mathrm{J}_{\mathrm{E}}^{\mathrm{k}}$ & - & 9 & \pm & 7 \\
\hline$(B 10 \times$ HTI) anti-B10.A(5R) & B10.A (3R) & $\mathrm{J}^{\mathrm{k}}$ & - & 3 & \pm & 2 \\
\hline$(B 10 \times$ HTI) anti-B10.A(5R) & A.TL & $c^{d}$ & - & 138 & \pm & 9 \\
\hline (B10 $x$ HTI) ant1-B10.A(5R) & B10.A & none & - & 169 & \pm 2 & 3 \\
\hline
\end{tabular}

1. Target macrophages and T-B cell fraction used in experiment.

2. This is based on the potential reactivity of the antiserum with consideration being given to the subregions of the target macrophage.

3. PFC are expressed as the mean \pm SD of quadruplicate cultures plaqued twice on Day 5 of the culture.

B10.S(9R) spleen cells removes activity directed against the $I-J$ subregion of the $k$ haplotype. The adsorbed sera has strong cytotoxic activity against primarily Ia. 3 located in the $I-A$ subregion. Although this adsorbed sera deletes the same percentage of macrophages as the unadsorbed sera, the PFC response is not affected. Two pairs of intra-I region recombinant strains were critical to these mapping experiments, the B10.A(5R) $\left(H-2^{i 5}\right), \mathrm{B} 10 . \mathrm{A}$ (3R) $\left(H-2^{i s}\right)$ pair and the B10.HTT $\left(H-2^{t s}\right)$, B10.S(9R) $\left(H-2^{t 4}\right)$ pair. These strain pairs differ at the $I-J$ subregion (Murphy 1976). When the A.TH antiA.TL serum is adsorbed with B10.HTT spleen cells, antibodies directed to specificities of the $I-J$ subregion of the $k$ haplotype should not be removed. 
TABLE III

Effect on macrophage function in the in vitro antibody response by treatment with selectively adsorbed anti-Ia serum and complement

A.TH s-'sssss-ssd $[4,5,9,12,17,18]$

\begin{tabular}{|c|c|c|c|c|}
\hline \multirow{2}{*}{$\begin{array}{l}\text { Antiserum Treatment } \\
\text { of Macrophages }\end{array}$} & \multirow{2}{*}{$\begin{array}{l}\text { Antiserum } \\
\text { Adsorbed with }\end{array}$} & \multirow{2}{*}{$\begin{array}{l}\text { Relevant } \underline{I} \\
\text { Subregions }\end{array}$} & \multicolumn{2}{|c|}{ PFC/Dish $\underset{ \pm}{\mathrm{IgM}} \mathrm{SD}$} \\
\hline & & & Exp. 1 & Exp. 2 \\
\hline$-\quad \cdot$ & - & - & $185 \pm 4$ & $274 \pm 10$ \\
\hline A.TL anti-A.TH & - & $A^{s} B^{s} J^{s} E^{s} C^{s}$ & $19 \pm 3$ & $2 \pm 1$ \\
\hline A.TL anti-A.TH & B10.A & $A^{s} B^{s} J^{s} E^{s} C^{s}$ & $96 \pm 13$ & $6 \pm 10$ \\
\hline A.TL anti-A.TH & B10.S (9R) & $J^{s} E^{s} C^{s}$ & $66 \pm 9$ & $55 \pm 11$ \\
\hline A.TL anti-A.TH & B10. HTT & $E^{s} C^{s}$ & $194 \pm 8$ & $237 \pm 5$ \\
\hline A.TL anti-A.TH & B10.S & none & $274 \pm 24$ & - \\
\hline A.TL anti-B10. HTT & - & $A^{S} B^{S} J^{s}$ & $22 \pm 11$ & $49 \pm 36$ \\
\hline A.TL anti-B10. HTT & B10.A & $A^{s} B^{s} J^{s}$ & $71 \pm 34$ & $3 \pm 3$ \\
\hline A.TL anti-B10.HTT & B10.S (9R) & $\mathrm{J}^{\mathrm{s}}$ & $73 \pm 12$ & $7 \pm 11$ \\
\hline A.TL anti-B10. HTT & B10. HTT & none & $277 \pm 31$ & $248 \pm 21$ \\
\hline$(\mathrm{A} \times \mathrm{B} 10 . \mathrm{D} 2)$ anti-B10.A(5R) & EL-4 & $\mathrm{A}_{9}^{\mathrm{b}}$ & - & $35 \pm 28$ \\
\hline
\end{tabular}

Similar results were obtained when B10.A(3R) and B10.A(5R) spleen cells were used to adsorb the antiserum (A.TH $\times$ B10.HTT) anti-A.TL (Table II).

In Table III the anti-Ia antibodies were directed at specificities of the $s$ haplotype. Again, the B10.S(9R) and B10.HTT strains were used to adsorb the anti-Ia serum. Adsorption with B10.HTT spleen cells removed antibodies directed to specificities of the $I-J$ subregion of the $s$ haplotype, resulting in a serum which no longer could remove the relevant macrophages. In this experiment the antiserum A.TL anti-B10.HTT was also tested. Adsorbing this serum with B10.S(9R) spleen cells results in a serum with antibodies directed at only the $I-J$ subregion of the $s$ haplotype. This adsorbed serum retained its capacity to eliminate the function of the relevant macrophage. This was not the case when this anti-Ia serum was adsorbed with B10.HTT as can be seen in Table III. The third anti-Ia serum tested in this experiment was (B10.A $\times$ B10.D) anti-B10.A(5R). This serum has 
antibody activity for $H-2.33$ and for Ia.9 and Ia.20. Adsorption of this serum with EL-4 cells removed the H-2.33 activity but did not adsorb the Ia.9 and Ia. 20 activity. In this experiment the adsorbed serum was effective in removing macrophage function. This is best explained as the ability of the antibodies in the serum specific for Ia.9 of the $b$ haplotype to cross react with the same specificity of the $s$ haplotype.

The pattern which emerged from these experiments clearly demonstrated that antibodies specific for the $I-J$ subregion of the $H-2^{k}$ and $H-2^{s}$ haplotypes could eliminate the macrophages required for the primary antibody response. It has been more difficult to be certain about the importance of the $I-E$ subregion to the role of the macrophage. This region was mapped to the interval between $I-B$ and $I-C$ by David (Shreffler et al. 1977) on the basis of a serologically detectable Ia determinant on spleen cells. Evidence for the existence of the $I-E$ subregion was obtained from the cytotoxic reaction of (C3H.Q $\times$ B10.D2) anti-B10.AQR antibodies for $H-2^{k}$ lymphoid cells. An unexpected finding was that this serum also killed B10.A(5R) cells. Adsorption analysis of this antiserum confirmed the interpretation that the reaction against B10.A(5R) defined a new specificity Ia.22, a private specificity of $H-2^{k}$. The $I-E$ subregion has been further defined as expressing Ia.7 (formerly thought to be a product of $I-C$ ), a public specificity of haplotypes $k, d, p$ and $r$; Ia.21, a private specificity of $p$ and Ia.23, a private specificity of $d$ (David, personal communication). The results of the experiments performed to date indicate that antibodies specific for Ia.22 were not able to eliminate the relevant macrophages. For example, (C3H.Q $\times$ B10.D2) anti-AQR serum and complement treatment of B10.A(5R) macrophages, and B10.A(3R) macrophages, eliminated the relevant macrophages necessary to reconstitute the primary antibody response (Table IV). As indicated, the reaction of this antiserum on B10.A(5R) should be directed at specificity Ia.22 of the $I-E$ subregion or the $I-J$ subregion. Antibodies specific for Ia.22 should not be adsorbed by B10.A(4R) lymphoid cells (Ia.2, $17,18,19)$ but when this adsorption was performed the anti-AQR serum no longer deleted the required macrophages in the in vitro primary antibody response.

These results may indicate that antibodies specific for Ia.22 cannot remove or interfere with macrophage function as measured in this functional assay and that the inhibited response is due to antibodies directed at the $I-J$ subregion. One should recall that anti-I-J antibodies have not been detected serologically, such as in dye exclusion assays (Murphy et al. 1976). The definition of $I-J$ subregion activity has depended on the ability of antibodies to eliminate functional cells from assay systems or to adsorb biologically active molecules. The anti-AQR serum and complement were ef- 
TABLE IV

Reactivity of antiserum (C3H.Q $\times$ B10.D2) Anti-AQR with macrophages required for antibody response

\begin{tabular}{|c|c|c|c|c|}
\hline Target Ce1I & $\begin{array}{l}\text { Relevant Ia } \\
\text { Determinants }\end{array}$ & $\frac{\text { Percent Response }}{\text { Unabsorbed }}$ & $\begin{array}{l}\text { Reduction }{ }^{1} \\
\text { Adsorbed with } \\
\text { B10.A(4R) } \\
(2,17,18,19)\end{array}$ & $\begin{array}{l}\text { Anti-I-J } \\
\text { Activity } \\
\text { Remaining }\end{array}$ \\
\hline B10.S (9R) & $17,18,22$ & $97 \%$ & & yes \\
\hline B10. HTT & $17,18,22$ & $97 \% ; 88 \%$ & & no \\
\hline B10.A(5R) & 22 & $95 \% ; 65 \% ; 83 \%$ & $0 \%$ & yes \\
\hline B10.A (3R) & 22 & $73 \% ; 73 \%$ & $0 \%$ & no \\
\hline $\mathrm{B} 10 . \mathrm{A}(4 \mathrm{R})$ & $2,17,18,19$ & $68 \%$ & & no \\
\hline
\end{tabular}

1. Each of the results in this table represents an individual experiment with controls. The percent reduction is based on the mean $\mathrm{PFC} /$ dish of quadruplicate cultures.

fective with both B10.A(5R) and B10.A(3R) target macrophages (Table IV) suggesting that antibodies produced against products of the $I-J$ subregion of the $k$ haplotype can cross react with those of the $b$ haplotype. David (Shreffler et al. 1977) also noted that B cells from B10.A(3R) and B10.A (5R) appeared to completely adsorb anti-AQR serum cytotoxicity for target $\mathrm{T}$ cells from B10.A(3R) but not for B10.A(5R) T cell targets. He also observed that $\mathrm{T}$ cells from B10.A(3R) did not adsorp cytotoxic activity for B10.A(5R) T cells.

Two important antisera which have high titers and were useful in defining critical macrophage function to the $I-J$ subregion were sera produced in $\mathrm{F}_{1}$ hybrids of $($ A.TH $\times$ B10.HTT) and (A.BY $\times$ B10.HTT) immunized with A.TL lymphoid cells (see Table I). These two antisera do not contain antibodies against $I-E^{k}$ or $I-C^{k}$ subregions since these subregions of donor strain A.TL are blocked by the presence of $I-E^{k}$ and $I-C^{k}$ in strain B10.HTT in the antiserum producer. The results of titration of these two antisera against a panel of targets are presented in Table V. The results indicate that they were essentially the same with major activity for specificities $1,2,19$. The antiserum (A.TH $\times$ B10.HTT) $\mathrm{F}_{1}$ anti-A.TL had weak reactivity with Ia.3 which is not recognized by the (A.BY $\times$ B10.HTT) $F_{1}$ anti-A.TL serum. Both antisera should be reactive with products of the $I-J^{k}$ subregion. The results of treating macrophages with these antibodies and complement prior to using the macrophages in an in vitro primary antibody response are summarized in Table VI. When these anti-A.TL sera are tested on B10.S(9R) $\left(I-J^{k}\right)$ the only relevant antibodies should be directed at products of the I-J subregion. The response in each experiment was significantly reduced. As 
TABLE V

Titrations of antiserum against lymphoid cells of selected $\mathrm{H}-2$ haplotypes

\begin{tabular}{lcccc}
\hline Strain & $\begin{array}{c}\text { Titer1 } \\
\text { A.TH x B10.HTT) F } \\
\text { Anti-A.TL }\end{array}$ & $\begin{array}{l}\text { Relevant Ia } \\
\text { Specificities }\end{array}$ & $\begin{array}{c}\text { (ABY x B10.HTT) F } \\
\text { Anti-A.TL }\end{array}$ & $\begin{array}{c}\text { Relevant Ia } \\
\text { Specif1cities }\end{array}$ \\
\hline A.TH & 0 & - & 0 & - \\
A.TL & 256 & $1,2,3,15,19$ & 1024 & $1,2,19$ \\
B10.A(3R) & 4 & 3,15 & 0 & - \\
B10.A(4R) & 256 & $1,2,3,15,19$ & 512 & $1,2,19$ \\
B10.A(5R) & 4 & 3,15 ?-J & 0 & - \\
B10.HTT & 0 & - & 0 & - \\
B10.S(9R) & 0 & $-?-J$ & 0 & - \\
B10.D2 & 0 & 15 & 0 & - \\
B10 & 4 & 3,15 & 0 & - \\
B10.A & 256 & $1,2,3,15,19$ & 512 & $1,2,19$ \\
\hline
\end{tabular}

1. Determined in microcytotoxic dye exclusion assay.

TABLE VI

Reactivity of restricted antisera with macrophages required for antibody response

\begin{tabular}{lcccc}
\hline Target Ce11 & $\begin{array}{c}\text { Relevant Ia } \\
\text { Determinants }\end{array}$ & $\begin{array}{c}\text { Relevant } \\
\text { Region }\end{array}$ & $\begin{array}{c}\text { Percent Response Reduction } \\
\text { Reg.TH } \times \text { B10.HTT) } F_{1} \\
\text { Anti-A.TL }\end{array}$ & $\begin{array}{c}\text { (ABY } \times \text { B10.HTT) } F_{1} \\
\text { Anti-A.TL }\end{array}$ \\
\hline \hline B10.A(3R) & 3,151 & no & $94 \% ; 85 \%$ & - \\
B10.A(5R) & 3,15 & yes & $93 \% ; 56 \% ; 54 \%$ & $96 \%$ \\
B10.S(9R) & -- & yes & $88 \% ; 58 \% ; 42 \%$ & $95 \%$ \\
B10.HTT & - & no & $8 \% ; 0 \%$ & -- \\
B10.BR & $1,2,3,15,19$ & yes & $97 \% ; 98 \% ; 96 \% ; 75 \% ; 89 \%$ & $94 \%$ \\
B10.A(4R) & $1,2,3,15,19$ & no & $69 \%$ & - \\
\hline
\end{tabular}

1. Although the (A.TH $\times$ B10.HTT) $F_{1}$ Anti-A.TL serum could react with specificities Ia.3 and Ia.15, microcytotoxic tests indicated only weak activity with Ia.3.

anticipated these anti-A.TL sera had no such effect on B10.HTT target macrophages which differ from the B10.S(9R) macrophages at the $I-J$ subregion. When the $(\mathrm{A} . \mathrm{TH} \times \mathrm{B} 10 . \mathrm{HTT}) \mathrm{F}_{1}$ anti-A.TL sera was adsorbed with B10.A(5R) spleen cells only the activity directed at the $I-J^{k}$ subregion should have been removed. Antibodies to specificities Ia.1, 2, 19, of the $I-A^{k}$ subregion should have remained but, as shown (Table VII), the ability to delete 
TABLE VII

Adsorption analysis of antiserum $\left(\right.$ A.TH $\times$ B10.HTT) $F_{1}$ Anti-A.TL

\begin{tabular}{lccc}
\hline $\begin{array}{l}\text { Antiserum } \\
\text { Adsorbed } \\
\text { With }\end{array}$ & $\begin{array}{c}\text { Percent Response } \\
\text { Reduction } 1 \\
\text { Target B10.BR } \\
{[1,2,3,15,19]}\end{array}$ & $\begin{array}{c}\text { Anti-Ia } \\
\text { Specificities } \\
\text { Remaining }\end{array}$ & $\begin{array}{c}\text { Anti-I-J } \\
\text { Activity } \\
\text { Remaining }\end{array}$ \\
\hline-- & $95 \% ; 100 \%$ & $1,2,3,15,19$ & yes \\
B10 & $91 \% ; 96 \%$ & $1,2,19$ & yes \\
B10.A(3R) & $88 \% ; 96 \%$ & $1,2,19$ & yes \\
B10.A(5R) & $0 \% ; 35 \%$ & $1,2,19$ & no \\
B10.A(4R) & $82 \% ; 93 \%$ & -- & yes \\
B10.A & $31 \%$ & -- & no \\
\hline
\end{tabular}

1. Data from experiments detailed in Table II.

the function of relevant macrophages is lost. The extensive testing to date has thus strongly implicated the determinants of the $I-J$ subregion expressed on macrophages as essential to the primary in vitro antibody response.

\section{Anti-Ia antibody blocking of macrophage-T lymphocyte interaction} in the primary in vitro humoral response

The deletion of a subset of the macrophage population which was essential to effect an in vitro antibody response by anti-Ia antibodies and complement did not answer questions concerning the role of the Ia molecule in the response. As an initial step to look at this problem, macrophages prepared as described were incubated for $30 \mathrm{~min}$ with appropriate anti-Ia antibodies. The serum was decanted and the macrophages washed by adding and decanting fresh culture media three times. No complement was used. The T-B cell fraction of the spleen population and antigen were added to the dishes of macrophages. The PFC response was assayed on Day 5. These experiments (Table VIII) demonstrated that inhibition of the response occurred at the level of the macrophage-Ia determinants. Of significance was the observation that blocking of the response only occurred when the anti-Ia sera included antibodies reactive with the appropriate $I-J$ subregion.

It was important to tie together the results obtained with anti-Ia antibodies and complement and the results obtained with only anti-Ia anti- 
TABLE VIII

Blocking of macrophage function in the in vitro humoral response by preincubation with anti-Ia sera directed against various I subregions

\begin{tabular}{|c|c|c|c|c|}
\hline Antiserum & & Target $\mathrm{M} \phi$ & $\begin{array}{l}\text { Relevant I I } \\
\text { Subregion }\end{array}$ & $\begin{array}{c}\% \\
\text { Inhibition }\end{array}$ \\
\hline A.TL anti-A.TH & & B10.S (9R) & $A^{S} B^{S}$ & 0 \\
\hline A.TL anti-A.TH & & B10.S (9R) & $A^{s} B^{s}$ & 0 \\
\hline A.TH anti-A.TL & & B10.S (9R) & $J^{k} E^{k} C^{d}$ & 98 \\
\hline A.TH anti-A.TL & & B10.S (9R) & $J^{k} E^{k} C^{d}$ & 45 \\
\hline A.TH anti-A.TL & & B10.S (9R) & $\mathrm{J}^{\mathrm{k}} \mathrm{E}^{\mathrm{k}} \mathrm{C}^{\mathrm{d}}$ & 52 \\
\hline A.TH anti-A.TL & & B10. HTT & $\mathrm{E}^{\mathrm{k}} \mathrm{C}^{\mathrm{k}}$ & 0 \\
\hline A.TH anti-A.TL & & B10.HTT & $\mathrm{E}^{\mathrm{k}} \mathrm{C}^{\mathrm{k}}$ & 0 \\
\hline (A.THxB10.HTT) & anti-A.TL & $\mathrm{B} 10 . \mathrm{A}(5 \mathrm{R})$ & $A^{b} B^{b} J^{k}$ & 49 \\
\hline (A.THxB10.HTT) & anti-A.TL & $\mathrm{B} 10 . \mathrm{A}(5 \mathrm{R})$ & $A^{b} B^{b} J^{k}$ & 58 \\
\hline
\end{tabular}

1. Each of the results in this Table represents an individual experiment with controls. The percent inhibition is based on the PFC/DISH expressed as the mean of quadruplicate cultures stimulated with burro erythrocytes. (Ref. Shreffler et al. 1977).

bodies. Experiments were designed in which both blocking and lysis using complement were compared in the same experiments (Table IX). All of the results are compared to the complement control utilizing an inappropriate anti-Ia sera [A.TL $\times$ B10.S $(9 R)] F_{1}$ anti-A.TH serum. When B10.S (9R) macrophages were treated with A.TL anti-A.TH serum and complement, the response was reduced $72 \%$. When complement was omitted, however, the response was not significantly reduced. This supported earlier interpretations that although antibodies produced against determinants of the $I-A^{s}$ and $I-B^{s}$ subregions could delete $H-2^{s}$ macrophages these determinants were not critically involved in the interaction between macrophages and $\mathrm{T}$ lymphocytes. Similar results were obtained in this experiment with the antiserum B10.A(7R) anti-B10.HTT against $I-E^{k}$ subregion.

As previously noted the antiserum (A.TH $\times$ B10.HTT) anti-A.TL when used against B10.S(9R) targets was specific for the $I-J^{k}$ subregion. This antiserum reduced the response by $88 \%$ when complement was used and by $81 \%$ when complement was omitted. If the $I-J$ subregion product was involved in antigen presentation or in macrophage- $T$ lymphocyte inter- 
TABLE IX

Effect of anti-Ia antibodies on macrophage function in a primary in vitro response to $B R B C$

TARGET CELLS: B10.S(9R) s - sskkd - ddd $[4,5,6,7,9,12,17,18,22]$

\begin{tabular}{|c|c|c|c|c|c|}
\hline \multirow{2}{*}{$\begin{array}{l}\text { Antiserum Treatment } \\
\text { of Macrophages } \\
\\
\text { Macrophages }\end{array}$} & \multirow[t]{2}{*}{$\begin{array}{l}\text { Relevant } \\
\text { I Region }\end{array}$} & \multicolumn{4}{|c|}{$\begin{array}{l}\operatorname{IgM} \\
S H \pm S . D .\end{array}$} \\
\hline & & & & \pm & 5 \\
\hline Macrophage Depleted & & & & \pm & 4 \\
\hline Reconstitution ${ }^{1}$ & none & & 860 & \pm & 110 \\
\hline$[\mathrm{A} . \mathrm{TH} \times \mathrm{B} 10 . \mathrm{S}(9 \mathrm{R})] \propto \mathrm{A} \cdot \mathrm{TL}^{3}$ & none & $\begin{array}{l}\text { (Lysis) } \\
\text { (Blocked) }\end{array}$ & $\begin{array}{l}878 \\
737\end{array}$ & $\begin{array}{l} \pm \\
\pm\end{array}$ & $\begin{array}{r}5 \\
84\end{array}$ \\
\hline A.TL $\propto$ A.TH & $A^{s} B^{s}$ & $\begin{array}{l}\text { (Lysis) } \\
\text { (Blocked) }\end{array}$ & $\begin{array}{l}246 \\
534\end{array}$ & $\begin{array}{l} \pm \\
\pm\end{array}$ & $\begin{array}{l}30 \\
88\end{array}$ \\
\hline [A.TH $\times$ B10.HTT] $\alpha$ A.TL & $\mathrm{J}^{\mathrm{k}}$ & $\begin{array}{l}\text { (Lysis) } \\
\text { (Blocked) }\end{array}$ & $\begin{array}{l}106 \\
141\end{array}$ & $\begin{array}{l} \pm \\
\pm\end{array}$ & $\begin{array}{r}10 \\
5\end{array}$ \\
\hline B10.A (7R) $\propto$ B10.HTT & $\mathrm{E}^{\mathrm{k}}$ & $\begin{array}{l}\text { (Lysis) } \\
\text { (Blocked) }\end{array}$ & $\begin{array}{l}148 \\
411\end{array}$ & $\begin{array}{l} \pm \\
\pm\end{array}$ & $\begin{array}{l}21 \\
71\end{array}$ \\
\hline
\end{tabular}

1. $10^{7}$ macrophage depleted added to approximately $10^{6}$ macrophages.

2. The percentage viable recovered cells ranged from $26-51 \%$ /DISH. PFC are expressed as the mean \pm standard deviation of quadruplicate cultures plaqued twice on day 5 of the primary response.

3. Antisera for treatment were diluted $1: 10$ and $1 \mathrm{ml}$ of diluted sera was added to each dish to treat $\sim 10^{6}$ macrophages. In those conditions marked lysis the macrophages were sequentially treated with anti-Ia sera and rabbit complement.

action, then antibodies should be equally effective with or without complement. A series of such experiments has strongly supported the observations of earlier experiments which looked at either deletion or blocking with antiIa sera.

Anti-Ia antibody blocking of macrophage-T lymphocyte interaction in the secondary in vitro humoral response

Experiments were also performed to study the role of macrophages in the secondary in vitro antibody response. Four to 6 weeks after priming mice with $4 \times 10^{8} \mathrm{BRBC}$ i.v., their spleen cells were used to prepare macro- 
TABLE X

Effect of anti-Ia antibodies on macrophage function in a secondary in vitro response to $B R B C$

B10.S(9R) s- sskkd - kkd $[4,5,6,7,9,12,17,18,22]$

\begin{tabular}{|c|c|c|c|c|c|}
\hline $\begin{array}{l}\text { Antiserum Treatment } \\
\text { of Macrophages } 1\end{array}$ & $\underset{\text { Region }}{\text { Relevant }} \underline{I}$ & & $\begin{array}{l}\text { IgM } \\
\text { PFC/Dish } \\
\text { Exp.1 }\end{array}$ & $\pm \underset{\text { Exp. }}{\mathrm{SD}^{2}}$ & 2 \\
\hline Macrophages & & & $15 \pm 15$ & $14 \pm$ & 14 \\
\hline Macrophage Depleted Cells & & & $26 \pm 18$ & $25 \pm$ & 17 \\
\hline [A.TH $\times$ B10.S (9R)] $\propto$ A.TL & none & (Lysis) & $468 \pm 35$ & $436 \pm$ & 33 \\
\hline & & (Blocked) & $540 \pm 97$ & $459 \pm$ & 94 \\
\hline A.TL $\propto$ A.TH & $A^{S} B^{s}$ & (Lysis) & $135 \pm 47$ & $126 \pm$ & 44 \\
\hline & $\mathrm{k}$ & (Blocked) & $495 \pm 98$ & $439 \pm$ & 105 \\
\hline [A.TH $\times$ B10.HTT] $\propto$ A.TL & $\mathrm{J}^{\mathrm{K}}$ & (Lysis) & $118 \pm 47$ & $110 \pm$ & 44 \\
\hline & $k_{D} k$ & (Blocked) & $88 \pm 54$ & $82 \pm$ & 51 \\
\hline A.TH $\propto$ A.TL & $\mathrm{JE}$ & (Lysis) & $38 \pm 14$ & $35 \pm$ & 13 \\
\hline B10.A(7R) $\propto$ B10.HTT & $\mathrm{E}^{\mathrm{k}}$ & (Lysis) & $129 \pm 27$ & $121 \pm$ & 25 \\
\hline & & (Blocked) & $122 \pm 29$ & $112 \pm$ & 27 \\
\hline
\end{tabular}

Macrophages

Macrophage Depleted Cells

[A.TH x B10.S(9R)] $\alpha$ A.TL

A.TL $\propto$ A.TH

[A.TH $\times$ B10.HTT] $\propto$ A.TL

A.TH $\propto$ A.TL

B10. A(7R) $\alpha$ B10. HTT none

$$
A^{s} B^{s}
$$

$\mathrm{J}^{\mathrm{k}}$

$J^{k} E^{k}$

$\mathrm{E}^{\mathrm{k}}$
$\mathrm{IgG}^{3}$

$\mathrm{PFC} / \mathrm{Dish} \pm \mathrm{SD}$

Exp. 1

$3 \pm 4$
$2 \pm 4$

$2 \pm 4$
$318 \pm 98$

$212 \pm 44$

$8 \pm 15$

(Blocked)

(Lysis)

(Blocked)

(Lysis)

(Blocked)

(Lysis)

(Blocked)

(Lysis)

(Blocked)
Exp. 2

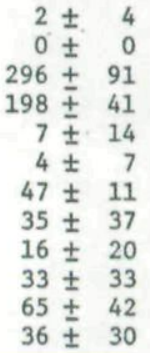

1. Antisera for treatment of macrophages were diluted 1:10 and $1 \mathrm{ml}$ of diluted sera was added to each dish to treat $\sim 10^{6}$ macrophages. In those conditions marked (Lysis) the macrophages were sequentially treated with anti-Ia sera and rabbit complement. Macrophages were further treated with mitomycin-C. $10^{7}$ macrophage depleted lymphocytes were added to each dish and cultures stimulated with BRBC.

2. PFC are expressed as the mean \pm standard deviation of quadruplicate cultures plaqued twice on Day 5 of the secondary response to BRBC.

3. Developed with rabbit anti-mouse $\gamma$ chain in presence of anti- $\mu$ chain sera. There are no PFC with anti- $\mu$ chain sera alone.

phage and T-B lymphocyte fractions. The macrophages were treated with either anti-Ia antibodies or with anti-Ia sera and complement. The macrophages were then treated with mitomycin-C. The T-B cell fraction and BRBC were added and, after 5 days of culture, the dishes were assayed for secondary IgM and IgG-PFC. 
TABLE XI

Effect of anti-Ia antibodies on macrophage function in a secondary in vitro response to $B R B C$

B10.A(5R) b-bbkkd-ddd $[3,6,7,8,9,15,20,22]$

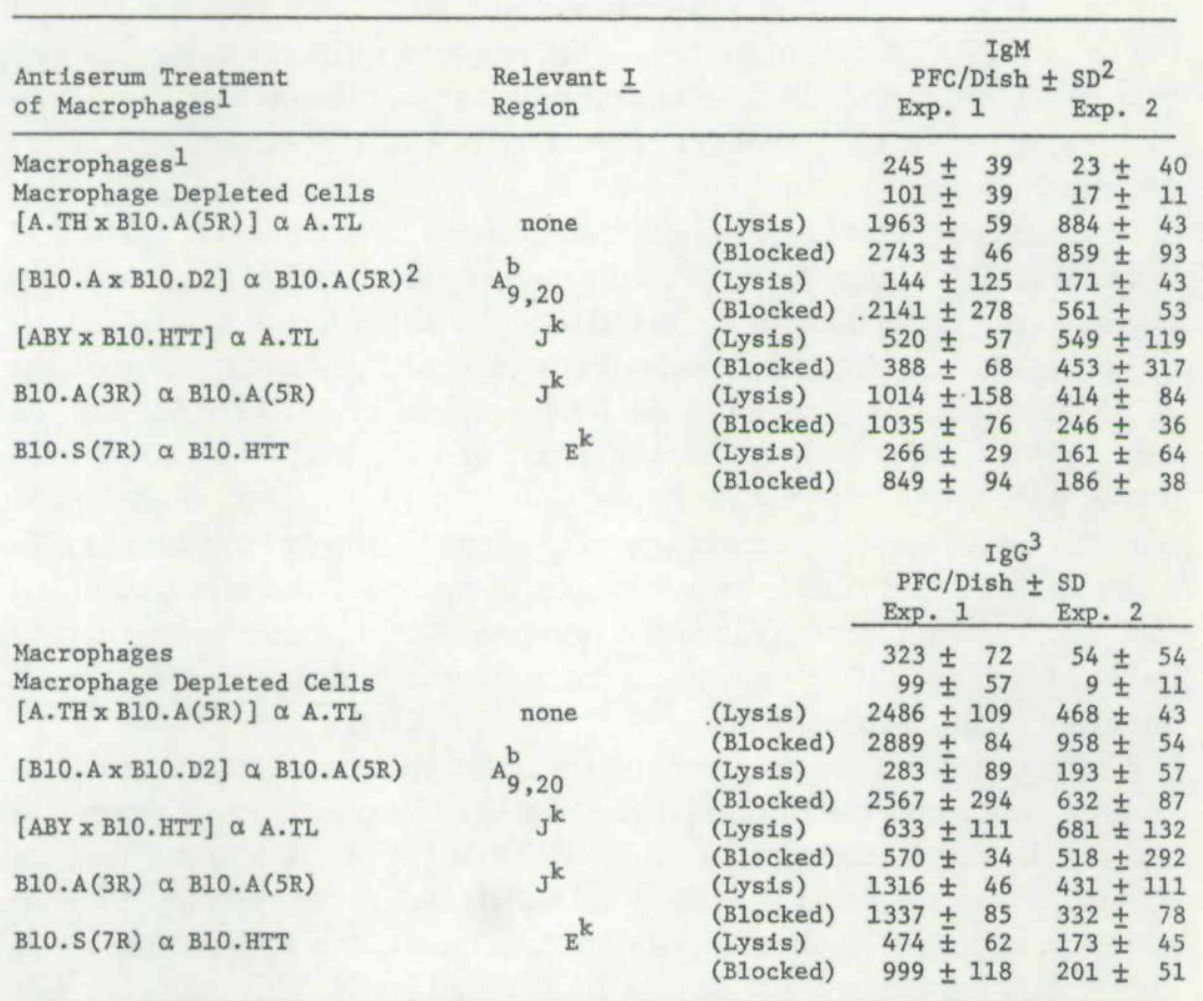

1., 2. See Table $X$, footnote 1 and 2 .

3. Developed with anti-mouse $\gamma$ chain sera. The sera was tested for IgM-PFC breakthrough using LPS primed spleen cells and found to be $\leqq 15 \%$.

The effect of restricted anti-Ia sera on the secondary IgM-PFC response of B10.S(9R) macrophages (Table X) was essentially the same as that observed for the primary response (Table IX). Antibodies specific for the $I-A^{s}$ and $I-B^{s}$ subregions did not block the ability of the macrophages to function in the response. However, when complement was used in the antiIa sera treatment the response was significantly reduced. The two antisera $($ A.TH $\times$ B10.HTT) anti-A.TL and A.TH anti-A.TL have the potential of reacting with membrane products of the $I-J^{k}$ subregion of B10.S(9R) macrophages. If the $I-J$ subregion is involved in antigen presentation and/or macrophage-T cell interaction, then these antibodies should be effective in re- 
ducing the response with or without complement. This was observed in these two experiments (Table $\mathrm{X}$ ) and in experiments using $\mathrm{B} 10 . \mathrm{A}(5 \mathrm{R})$ target macrophages (Table XI).

The results obtained using the antisera B10.A(7R) anti-B10.HTT have not been as clear. In the two experiments with B10.S(9R) macrophages and the two with B10.A(5R) macrophages the response was significantly reduced with or without complement. In one other experiment, however, the response was reduced only when complement was used with the antisera. (Data not presented).

In these preliminary experiments using primed cells from $\mathrm{B} 10 . \mathrm{S}(9 \mathrm{R})$ and from $B 10 . A(5 R)$ mice, there was a definite requirement for the Ia positive macrophage subpopulation. In the B10.S(9R) experiments (Table X) all of the anti-Ia sera used even without complement significantly reduced the IgG-PFC response regardless of the I-subregion involved. This was not the case with $\mathrm{B} 10 . \mathrm{A}(5 \mathrm{R})$ primed macrophages, at least when the anti-Ia antibodies were specific for the $I-A^{b}$ subregion. The EL-4 adsorbed (B10.A $\times$ $B 10 . D 2)$ anti-B10.A(5R) serum was very effective when used with complement to delete the macrophage. Without complement the anti-B10.A(5R) sera did not significantly reduce the response. Anti- $I-J^{k}$ sera were effective in both blocking and deletion of the macrophages as determined by the reduced IgG PFC response.

Although these secondary results are quite preliminary there seems to be little doubt that the Ia positive macrophage is required for the response and for the development of IgG-PFC. It is not yet possible to say that the $I-J$ region has the same significant role as found in the primary in vitro antibody response. In the B10.A(5R) experiments, the $\mathrm{IgG}$ response was significantly reduced but not to near background levels. This may be a factor of antibody titer and will have to be tested. Since anti-I-J subregion activity can not be determined in microcytotoxic assay, it is difficult to know the exact titer at which to use these sera in functional assays. The titer of the $\mathrm{B} 10 . \mathrm{A}(3 \mathrm{R})$ anti-B10.A(5R) sera may be improved by producing the antibodies in [B10.A(3R) $\times \mathrm{B} 10 . \mathrm{D} 2] \mathrm{F}_{1}$ recipients.

\section{Genetic restriction at the I-J subregion for the effective interaction of}

\section{macrophages and lymphoid cells}

A number of investigators have demonstrated that allogeneic macrophages are as effective as syngeneic macrophages in stimulating mouse lymphoid cells in an in vitro antibody response (Hartmann et al. 1970, Kapp et al. 1973, Katz \& Unanue 1973, Pierce et al. 1974b, Pierce \& Kapp 1976). This is not the case, however, in the guinea pig where macrophages and $\mathrm{T}$ cells 
must be syngeneic for successful development of a proliferative response to antigen (Rosenthal \& Shevach 1973, 1976).

We have performed similar experiments using the multideterminant Tcell dependent antigen BRBC in a primary in vitro antibody response. In these experiments the differences between macrophages and the T-B fraction were restricted to segments of the $I$ region. The macrophages were treated with mitomycin-c before the addition of lymphoid cells and anti-

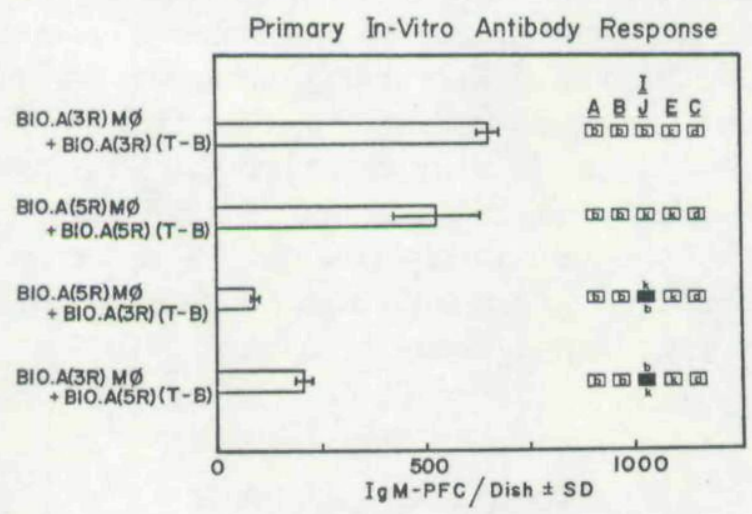

Figure 3. Primary in vitro antibody response to BRBC when macrophages and lymphoid cells differ at the I-J subregion. The response bars represent the mean \pm standard deviation of quadruplicate dishes with each dish plaqued twice on Day 5 of culture. The response of control cultures of macrophages alone or macrophage depleted cells were $<10 \mathrm{PFC} /$ dish.

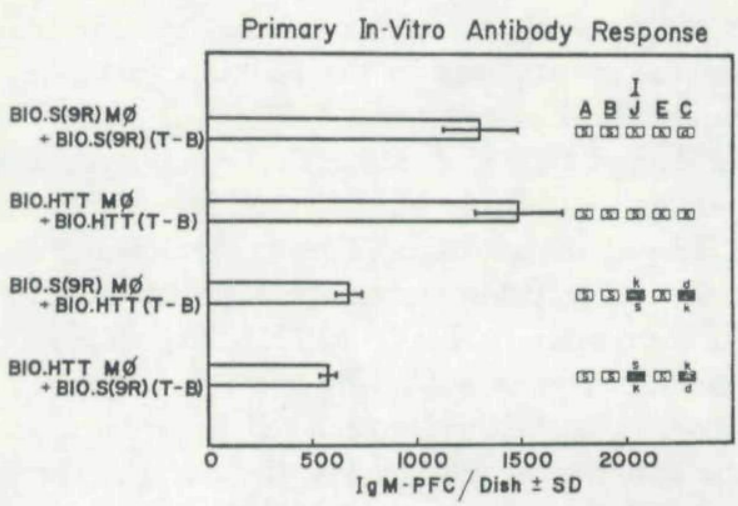

Figure 4. Primary in vitro antibody responses to BRBC when macrophages and lymphoid cells differ at $I-J$ subregion. There is an additional difference at $I-C$ subregion in this combination. The response of control cultures of macrophages alone or macrophage depleted cells were $<10 \mathrm{PFC} /$ dish. 
gen. When the macrophages and the T-B fraction differed at the entire $I$ region or when there were multiple subregion differences the IgM-PFC response was as good or actually enhanced when compared to syngeneic controls. This was especially true when the incompatibility was located to the left side of the $I$ region.

Much different results were obtained, however, if the $I$ region incompatibility was restricted to the $I-J$ subregion. In these experiments there was a highly significant reduction of the response indicating the requirement for genetic compatibility at the $I-J$ subregion for an effective response (Figures 3 and 4). These two experiments have been repeated on several occasions with identical results. Experiments testing other subregion differences are in process. These results add further support for the role of an $I-J$ region product(s) in antigen presentation and macrophage- $T$ lymphocyte interaction. It is possible that the reduced response is not due to an inability of receptor interaction between macrophages and $\mathrm{T}$ lymphocytes secondary to allogeneic differences at $I-J$ but is the result of active suppression. Experiments are underway to further clarify this question.

\section{CONCLUDING REMARKS}

It has been established that macrophages are required for the development of antibody responses to complex multideterminant, $\mathrm{T}$ cell-dependent antigens. The experiments reviewed in this manuscript clearly indicate that it is an Ia positive macrophage which is critical to the in vitro antibody response. By using restricted anti-I region sera and selected target macrophages, these experiments appear to map the involved $I$ region gene products (Ia antigens) on the macrophage to the $I-J$ subregion. This conclusion is drawn from a number of observations. I. The two antisera (A.TH $\times$ B10. HTT) $F_{1}$ anti-A.TL and (A.BY $\times$ B10.HTT) $F_{1}$ anti-A.TL effectively delete with complement and effectively block in the absence of complement the function of B10.S(9R) macrophages. The antibodies in these two antisera are only directed at $I-J^{k}$ determinants when tested on B10.S(9R) macrophages. II. The antiserum (A.TH $\times$ B10.HTT) $F_{1}$ anti-A.TL is restricted to react with determinants of $I-A^{k}, I-B^{k}$ and $I-J^{k}$ subregions. When this antiserum is selectively adsorbed with spleen cells from intra I-region recombinant strains, the antibody activity against the relevant macrophages is adsorbed by $\mathrm{B} 10 . \mathrm{A}(5 \mathrm{R})$ but not by $\mathrm{B} 10 . \mathrm{A}(3 \mathrm{R})$ spleen cells. III. Antiserum $(B 10 \times \mathrm{HTI}) \mathrm{F}_{1}$ anti-B10.A(5R) adsorbed with B10.A(3R) spleen cells is specific for $I-J^{k}$ and effectively removes macrophage functions of B10.BR targets. IV. The antiserum A.TL anti-B10.HTT is restricted to react with 
$I-A^{s}, I-B^{s}$ and $I-J^{s}$ determinants. This serum adsorbed with B10.S(9R) spleen cells is specific for the $I-J^{s}$ subregion and effectively eliminates the $H-2^{s}$ macrophages.

It is important to recall that macrophages not only function to present antigen to the responding $\mathrm{T}$ cells and $\mathrm{B}$ cells but also function to support the viability of the lymphoid cells in culture. Their ability to support viability can in part be replaced by the presence of 2-mercaptoethanol in the cultures. It was for this reason that 2-mercaptoethanol was not used in the experiments described here. The viability of the various anti-Ia serum and complement treated macrophage supported cultures was carefully monitored in these experiments. No effect on the viability of lymphoid cells remaining in culture for 5 days was observed; indicating that the macrophages resistant to anti-Ia sera treatment were equally capable of sustaining the viability of the T-B cell fraction.

Macrophages are also capable of releasing soluble mediators which can either enhance or suppress in vitro antibody responses. It might be argued that the experiments described have altered the balance of these macrophage products. The design of the experiments indicates interference with a very early event in the initiation of the response and a mechanism which can be altered by the simple interaction of antibody with a membrane structure. Furthermore, the fact that anti-Ia sera treated macrophages can be blocked with mitomycin-C before reconstituting the cultures without altering the experimental observations opposes an explanation based on the triggering of increased suppression.

Our working model, therefore, continues to focus on the Ia molecule(s) or as yet unknown molecules which are products of the $I-J$ subregion as being critical to the mechanism of antigen presentation to the $\mathrm{T}$ lymphocyte. Evidence supports the hypothesis that Ir gene control of the immune response may occur at the level of the macrophage and it is our feeling that a product of the I-J region which may or may not be the Ir gene product functions as the antigen recognition molecule on the macrophage. Non-responder strains would simply lack this recognition molecule. It is not clear whether interaction of antigen with this macrophage molecule alters the antigen but it seems more reasonable that it does not. The macrophage- $\mathrm{T}$ lymphocyte interaction therefore requires a $\mathrm{T}$-cell receptor which can react with the antigen-macrophage determinant complex. Preliminary experiments indicating the requirement for $I-J$ region compatibility between macrophages and lymphocytes for an effective primary response further suggest that the T-cell receptor is a product of the $I-J$ region. Much more work is obviously necessary before we will have a clear understanding of this complicated but crucial early event in the response to antigen. 
Finally, two important facts must be kept in mind when interpreting these and experiments of others studying macrophage functions. First, the macrophage population is a very heterogeneous population as to function and the macrophage-T lymphocyte interaction is only a small part of its repertoire. Second, and at the present time perhaps most important, it is exceedingly difficult to prepare pure macrophages relatively free of lymphocytes. Our efforts continue to work toward the improved preparation of pure macrophage fractions and toward an explanation of the $I$ region product's function in macrophage dependent cell interactions.

\section{ACKNOWLEDGMENTS}

This work was supported in part by National Institutes of Health Grant AI14006. The author is the recipient of USPHS Research Career Development Award AI-00237 from the National Institute of Allergy and Infectious Diseases. I wish to thank Doctors Donald Shreffler, L. Claflin and E. Möller for their helpful discussions and continued encouragement. The technical assistance of L. Mayo, P. Shoffner, D. Smith and C. Rossio is greatly appreciated.

\section{REFERENCES}

Bullock, W. W. \& Möller, E. (1972) 'Spontaneous' B cell activation due to loss of normal mouse serum suppressor. Eur. J. Immunol. 2, 514.

Claman, H.N. \& Mosier, D.E. (1972) Cell-cell interaction in antibody production. Prog. Allergy 16, 40.

David, C. S. (1976) Serologic and genetic aspects of murine Ia antigens. Transplant. Rev. 30, 299.

David, C. S., Shreffler, D. C. \& Frelinger, J. A. (1973) New lymphocyte antigen system (Lna) controlled by the Ir region of the mouse H-2 complex. Proc. Nat. Acad. Sci. (Wash.) 70, 2509.

Dresser, D. W. \& Wortis, H. H. (1965) Use of an antiglobulin to detect cells producing antibody with low haemolytic efficiency. Nature 208, 859.

Fishman, M. \& Adler, F. L. (1963) Antibody formation initiated in vitro. II. Antibody synthesis in $\mathrm{x}$-irradiated recipients of diffusion chambers containing nucleic acid derived from macrophages incubated with antigen. J. exp. Med. 117, 595.

Hämmerling, G. J. (1976) Tissue distribution of Ia antigens and their expression on lymphocyte subpopulations. Transplant. Rev. 30, 64.

Hartmann, K., Dutton, R. W., McCarthy, M. \& Mishell, R. I. (1970) Cell components in the immune response. II. Cell attachment separation of immune cells. Cell. Immunol. 1, 182.

Jerne, N. K. \& Nordin, A. A. (1963) Plaque formation in agar by single antibody-producing cells. Science 140, 405. 
Kapp, J. A., Pierce, C. W. \& Benacerraf, B. (1973) Genetic control of immune responses in vitro. II. Cellular requirements for the development of primary plaque-forming cell responses to the random terpolymer L-Glutamic acid ${ }^{60}-\mathrm{L}-\mathrm{Alanine} \mathrm{e}^{30}$-L-Tyrosine $^{10}$ by mouse spleen cells in vitro. J. exp. Med. 138, 1121.

Katz, D. H. \& Benacerraf, B. (1972) The regulatory influence of activated T cells on B cell responses to antigen. Adv. Immunol. 15, 1.

Katz, D. H. \& Unanue, E. R. (1973) Critical role of determinant presentation in the induction of specific responses in immunocompetent lymphocytes. J. exp. Med. 137, 967.

LY, I. A. \& Mishell, R.I. (1974) Separation of mouse spleen cells by passage through columns of sephadex G-10. J. Immunol. Methods 5, 239.

Mishell, R. I. \& Dutton, R. W. (1967) Immunization of dissociated spleen cell cultures from normal mice. J. exp. Med. 126, 423.

Murphy, D. B., Herzenberg, L. A., Okumura, K., Herzenberg, L. A. \& McDevitt, H. O. (1976) A new $I$ subregion $(I-J)$ marked by a locus $(I a-4)$ controlling surface determinants on suppressor T lymphocytes. J. exp. Med. 144, 699.

Niederhuber, J. E., Mayo, L., Allen, P. \& Shreffler, D. C. (1978) Requirement for macrophages bearing $I-J$ region $\mathrm{Ia}$ antigens in the primary in vitro antibody response. (Manuscript submitted for publication).

Niederhuber, J. E., Mayo, L. \& Shreffler, D. C. (1977) The requirement of Ia positive macrophages in the primary in vitro humoral response. In: Ia Antigens and Ir Gene. Ed.: McDevitt, H. O., Academic Press, New York (in press).

Niederhuber, J.E. \& Shreffler, D. C. (1977) Anti-Ia serum blocking of macrophage function in the in vitro humoral response. Transplant Proc. IX, 875.

Pierce, C. W. \& Kapp, J. A. (1976) The role of macrophages in antibody responses in vitro. In: Immunobiology of the Macrophages, p. 1. Ed.: Nelson, D. S., Academic Press, New York.

Pierce, C. W., Kapp, J. A., Solliday, S. M., Dorf, M. E. \& Benacerraf, B. (1974a) Immune response in vitro. XI. Suppression of primary $\operatorname{IgM}$ and $\operatorname{IgG}$ plaque-forming cell responses in vitro by alloantisera against leukocyte alloantigens. J. exp. Med. 140, 921.

Pierce, C. W., Kapp, J. A., Wood, D. D. \& Benacerraf, B. (1974b) Immune responses in vitro. X. Functions of macrophages. J. Immunol. 112, 1181.

Rabinovitch, M. \& DeStefano, M. J. (1975) Use of the local anesthetic lidocaine for cell harvesting and subcultivation. In Vitro 11, 379.

Rosenthal, A. S. \& Shevach, E. M. (1973) Function of macrophages in antigen recognition by guinea pig $\mathrm{T}$ lymphocytes. I. Requirement for histocompatible macrophages and lymphocytes. J. exp. Med. 138, 1194.

Rosenthal, A. S. \& Shevach, E. M. (1976) Macrophage-T lymphocyte interaction: The cellular basis for genetic control of antigen recognition. In: The Role of Products of the Histocompatibility Gene Complex in Immune Response, p. 335. Eds.: Katz, D. H. \& Benacerraf, B., Academic Press, New York.

Sabin, F. R. (1923) Studies of living human blood cells. Bull. Johns Hopkins Hosp. 34, 277 .

Schwartz, R. H., Dickler, H. B., Sachs, D. H. \& Schwartz, B. D. (1977) Studies of Ia antigens on murine peritoneal macrophages. Scand. J. Immunol. (in press).

Shreffler, D. C., David, C. S., Cullen, S. E., Frelinger, J. A. \& Niederhuber, J. E. (1977) Serological and functional evidence for further subdivision of the $I$ regions of the 
H-2 gene complex. In: Cold Spring Harbor Symp. Quant. Biol., p. 477. Cold Spring Harbor Laboratory, New York.

Sjöberg, O., Andersson, J. \& Möller, G. (1972) Requirement for adherent cells in the primary and secondary immune response in vitro. Eur. J. Immunol. 2, 123.

Unanue, E. R. (1972) The regulatory role of macrophages in antigenic stimulation. Adv. Immunol. 15, 95. 
This document is a scanned copy of a printed document. No warranty is given about the accuracy of the copy. Users should refer to the original published version of the material. 